\title{
THE STUDY OF NATURAL POLYSACCHARIDES: ORGANOLEPTIC, PHYSICAL, CHEMICAL, MICROBIOLOGICAL PROPERTIES, AND THERMODYNAMIC CHARACTERISTICS OF AQUEOUS SOLUTIONS
}

\author{
Dar'ya D. Belova*, Lyubov S. Dyshlyuk
}

Kemerovo Institute of Food Science and Technology (University), Stroiteley blvd. 47, Kemerovo, 650056 Russian Federation

Received May 01, 2016;

* e-mail: antonina-daria@mail.ru

Accepted in revised form June 18, 2016;

Published June 30, 2016

\begin{abstract}
Natural polysaccharides is a promising raw material for biodegradable polymers production. To properly select sources of their origin would require conformity with safety standards in force for the similar products. This work conducts a study with a view to examine the extent to which the organoleptic, physical and chemical properties of the polysaccharides in question, as well as their safety indicators conform with the provisions of GOST 16280-2002, CAS 11114-20-8 and CAS 9004-65-3. It is determined that the samples selected, namely, agar-agar produced by Panreac (Germany) and Helicon (USA), carrageenan produced by Boc Sciences (USA) and Newgreen Pharmchem Co. (China) and hydroxypropylmethyl cellulose produced by Acros (Belgium) and Ashland Aqualon Functional Ingredients (USA), meet safety requirements for this type of raw material. Simultaneously, we employ highsensitivity differential scanning calorimetry method to analyze thermodynamic characteristics of natural polysaccharides' aqueous solutions. It is shown that gels based on agar-agar have high melting temperature and can withstand temperature rise; after, their microscopic structure is not affected by thermal history, and the gel system remains stable. Thermodynamically, aqueous solution of kappa-carrageenan forms more stable gel than iota-carrageenan; strength and melting point of kappa-carrageenan gels can be adjusted by changing the concentration of potassium chloride in the solution. Aqueous solutions of hydroxypropylmethylcellulose are thermodynamically stable. The experimental data obtained confirm the feasibility of natural polysaccharides application in the production of biodegradable polymers.
\end{abstract}

Keywords: natural polysaccharides, agar-agar, carrageenan, hydroxypropyl methylcellulose, biodegradable polymers

\section{INTRODUCTION}

Nowadays, it is hard to find the sphere of human activity that does not employ polymer materials. As polymers production from petrochemicals increases due to their high demand, chemical stability of the synthetic polymers remains the problem at hand. The polymers can withstand well physical and chemical natural factors such as light, heat, humidity, atmospheric oxygen, as well as microbiological natural factors without any obvious signs of decomposition for decades. Polymers and their traces stay in the environment for a long time causing a substantial environmental damage $[1,2]$.

Similar problems occur upon synthetic polymers' disposal. Most synthetic materials emit poison gas during incineration, and contaminate groundwater in landfill as they do not rot down. Some countries (Taiwan, Germany, Ireland, and South Africa) now banned or limited the plastic bags usage. In addition, the declining oil and gas reserves tend to increase the cost of the materials [3].

Hence, it becomes important to produce modern polymeric materials from naturally occurring polymers, e.g. starch, chitosan, agar-agar, cellulose, carrageenan, pectin, etc. that will enter the biogeochemical cycle, and are environmentally safe due to their structure.

Unlike other plastics, biodegradable polymers will decompose into the low-molecular substances to take part in metabolism of protozoan species by acting chemically, physically, or biologically. Admittedly, this property of new materials will resolve the issue of waste disposal $[4,5]$.

Biodegradable polymers are produced by polymerizing the raw materials of biological origin. The latter are either extracted from plants and animals or synthesized using the commercial raw-materials processing technologies [6].

Biodegradable polymers offer substantial benefits in biocompatibility and environmental safety. Owing to that fact, they should see increasing application in medicine (disposable surgical products), pharmaceutical industry (medicines manufacturing), food industry (disposable packaging and tableware), and in agriculture (degradable films and bags) [7].

In simplistic terms, natural polysaccharidescontaining products belong to gel-like systems that

\footnotetext{
Please cite this article in press as: Belova D.D., Dyshlyuk L.S. The study of natural polysaccharides: organoleptic, physical, chemical, microbiological properties, and thermodynamic characteristics of aqueous solutions. Science Evolution, 2016, vol. 1, no. 1, pp. 72-79.

Copyright (C) 2016, KemSU. This is an open access article distributed under the terms of the Creative Commons Attribution 4.0 International License (http://creativecommons.org/licenses/by/4.0/), allowing third parties to copy and redistribute the material in any medium or format and to remix, transform, and build upon the material for any purpose, even commercially, provided the original work is properly cited and states its license. This article is published with open access at http://science-evolution.ru/.
} 
have complex distribution of water molecules. Gels are multi-component systems consisting of high-molecular substance (-s) and low-molecular liquid (water) [8].

Functional properties of polysaccharides suspensions depend on the $\mathrm{pH}$ value, temperature, particles sizes, surface structure, as well as composition such as salt content. Consequently, to practically introduce polysaccharides in actual multi-component systems would involve the assessment of the wide range of physical-chemical and functional properties $[9,10]$.

Therefore, it is desirable to comprehensively describe natural polysaccharides that are used in production of biodegradable polymers, their organoleptic, physical-chemical, thermodynamic properties, as well as safety.

\section{OBJECTS AND METHODS OF STUDY}

The objects of study includ the following polysaccharides: agar-agar, carrageenan, hydroxypropyl methylcellulose (HPMC). The natural polysaccharides under consideration display a range of suitable properties; as raw materials they have a potential to improve biodegradable polymers production processes.

Agar-agar is cold water-insoluble. It fully dissolves only at temperatures between 95 and $100^{\circ} \mathrm{C}$. The heated solution is transparent, and of limited viscosity. When cooled down to $35-40^{\circ} \mathrm{C}$ agar-agar forms clear and strong thermodynamically reversible gel. When heated to $85-95^{\circ} \mathrm{C}$ it melts to become a liquid solution and then, transforms back to gel at $35-40^{\circ} \mathrm{C}$.

Carrageenans are large, highly flexible molecules that curl forming helical structures. This permits the formation of a variety of gels at room temperature. The primary differences that affect properties essential to each carrageenans' class are the number and position of the ester sulfate groups on the repeating galactose units. Higher levels of ester sulfate lower the solubility temperature of the carrageenan producing the lower strength gels, and thus, contribute to gel inhibition (lambda carrageenan).

Among other implications, hydroproxypropyl methylcellulose is a stabilizer, an emulsifier and a thickening agent added to food to preserve and increase its viscosity.

For our study, we selected the following natural polysaccharides:

- agar-agar (Panreac, Germany);

- agar-agar (Helicon, USA);

- kappa-carrageenan (Boc Sciences, USA);

- iota-carrageenan (Newgreen Pharmchem Co., China);

- hydroproxypropyl methylcellulose (Acros, Belgium);

- hydroproxypropyl methylcellulose (Ashland Aqualon Functional Ingredients, USA).

To analyze the organoleptic, physical-chemical and microbiological properties tested, we referred to the following regulatory documents applicable to the natural polysaccharides under investigation:

- GOST 16280-2002 Food grade agar. Specifications;

- carrageenans. CAS 11114-20-8;

- hydroxypropyl methylcellulose. CAS 9004-65-3.
We employed the DSC 204 F1 high sensitivity differential scanning calorimeter (Phoenix ${ }^{\circledR}$, Germany) to determine thermodynamic quantities of polysaccharides aqueous solutions.

\section{RESULTS AND DISCUSSION}

To study the above-listed raw materials for purposes of practical application in biodegradable polymers production, we examined organoleptic, physical-chemical indicators, analyzed chemical and microbiological safety, and thermodynamic quantities of their aqueous solutions

Table 1 shows the results of examining agar-agar organoleptic properties from the producers selected.

Agar-agar organoleptic analysis indicates that the samples tested are in the form of homogenous lightcream powder with gray hue, without off-odors and off-taste; visible foreign impurities to the unaided eye not found.

Table 2 illustrates data obtained when testing physical-chemical properties of the agar-agar samples investigated.

The above-listed data proves that physical-chemical properties of both agar-agar samples satisfy the requirements.

Table 3 shows outcome of testing the microbiological and chemical safety of agar-agar, heavy metals content and microbiological indicators included.

Table 3 proves chemical and microbiological safety indicators of both agar-agar samples to satisfy the agaragar GOST 16280-2002 current requirements. The samples do not contain coliform bacteria, proteobacteria, and pathogenic microorganisms.

Based on the analysis of organoleptic and physicalchemical properties, as well as chemical and microbiological safety indicators it can be concluded that each of the agar-agar samples selected satisfies GOST 16280-2002 overall requirements and can be recommended for biodegradable polymers production.

Then, we assessed the organoleptic indicators of the carrageenans selected (USA, China). The experimental results are shown in Table 4. Analyzing the data we referred to the international food standards CODEX Alimentarius provisions, a CAS 11114-20-8 standard for carrageenans.

The results revealed that these caraggenan samples form homogenous fine powder of yellowish-white color without foreign taste or odor.

Table 5 presents data obtained upon examination of carrageenan physical-chemical properties.

As per data shown in Table 5, the carrageenan samples concerned display satisfactory results in regards to mass fraction of moisture. Within the limits of the norm are mass fractions of ash and sulfates. The samples are ethanol-insoluble, water-soluble at a temperature of $80^{\circ} \mathrm{C}$ therewith forming viscous transparent or slightly opalescent solutions.

Table 6 shows an outcome of examining the carrageenan chemical and microbiological safety, heavy metals content and microbiological indicators. 
Table 6 proves that chemical and microbiological safety indicators of both carrageenan samples meet the current CAS 11114-20-8 requirements of international food standards. The samples do not exhibit coliform bacteria and pathogenic microorganisms.
Similarly, in Table 7 we considered organoleptic properties of hydroproxypropyl methylcellulose (HPMC) from the producers selected (Belgium, USA) to compare the results against international food standards CODEX Alimentarius, a CAS 9004-65-3 standard for HPMC.

Table 1. The results of agar-agar organoleptic indicators' analysis

\begin{tabular}{|c|c|c|c|}
\hline \multirow[b]{2}{*}{ Indicator } & \multicolumn{2}{|c|}{ Sample } & \multirow[b]{2}{*}{ GOST $16280-2002$ provisions } \\
\hline & $\begin{array}{l}\text { The Panreac agar-agar } \\
\text { (Germany) }\end{array}$ & $\begin{array}{l}\text { The Helicon agar-agar } \\
\text { (USA) }\end{array}$ & \\
\hline Appearance & Homogenous powder & Homogenous powder & $\begin{array}{l}\text { Grist, granules, flakes, } \\
\text { powder, lamella, film }\end{array}$ \\
\hline Color & Light-cream with gray hue & Cream with gray hue & $\begin{array}{l}\text { Light-cream to dark-cream, } \\
\text { gray hue permitted }\end{array}$ \\
\hline $\begin{array}{l}\text { Odour, gel w/mass fraction of } \\
\text { dry matter } 0.85 \%\end{array}$ & $\begin{array}{c}\text { No off-odors, weak odor of } \\
\text { algae }\end{array}$ & No off-odors & No off-odors \\
\hline $\begin{array}{l}\text { Taste, gel w/mass fraction of } \\
\text { dry matter } 0.85 \%\end{array}$ & No off-taste & No off-taste & No off-taste \\
\hline Impurities & Not found & Not found & Shall not be permitted \\
\hline
\end{tabular}

Table 2. The results obtained through analysis of agar-agar physical-chemical indicators

\begin{tabular}{|c|c|c|c|}
\hline \multirow[b]{2}{*}{ Indicator } & \multicolumn{2}{|c|}{ Sample } & \multirow{2}{*}{$\begin{array}{l}\text { GOST } 16280-2002 \\
\text { provisions }\end{array}$} \\
\hline & $\begin{array}{l}\text { The Panreac agar-agar } \\
\text { (Germany) }\end{array}$ & $\begin{array}{l}\text { The Helicon agar-agar } \\
\text { (USA) }\end{array}$ & \\
\hline $\begin{array}{l}\text { Color, gel w/mass fraction of dry agar } \\
0.85 \% \text {, light transmission } \%\end{array}$ & $62.0 \pm 3.1$ & $65.0 \pm 3.3$ & Over 60.0 \\
\hline $\begin{array}{l}\text { Strength, gel } \mathrm{w} / \mathrm{mass} \text { fraction of dry agar } \\
0.85 \% \text { and sugar } 70 \% \text {, g }\end{array}$ & $1650 \pm 165$ & $1600 \pm 160$ & Over 1600 \\
\hline $\begin{array}{l}\text { Lowered strength after heating for } \\
2 \mathrm{hrs} \text {, gel w/mass fraction of dry agar } \\
0.85 \%, \%\end{array}$ & $10.0 \pm 1.0$ & $9.0 \pm 0.9$ & Under 10.0 \\
\hline $\begin{array}{l}\text { Melting temperature, gel w/mass fraction } \\
\text { of dry agar } 0.85 \%,{ }^{\circ} \mathrm{C}\end{array}$ & $82.0 \pm 8.2$ & $85.0 \pm 8.5$ & Over 80.0 \\
\hline $\begin{array}{l}\text { Gel-forming temperature, agar aqueous } \\
\text { solution gel w/mass fraction of dry agar } \\
0.85 \%,{ }^{\circ} \mathrm{C}\end{array}$ & $32.0 \pm 3.2$ & $32.0 \pm 3.2$ & Over 30.0 \\
\hline $\begin{array}{l}\text { Gel-forming temperature, agar aqueous } \\
\text { solution w/mass fraction of dry agar } \\
0.85 \% \text { and sugar } 70 \%,{ }^{\circ} \mathrm{C}\end{array}$ & $40.0 \pm 4.0$ & $42.0 \pm 4.2$ & Under 42.0 \\
\hline Mass fraction of water, $\%$ & $16.0 \pm 1.6$ & $17.5 \pm 1.8$ & Under 18.0 \\
\hline Mass fraction of ash, $\%$ & $4.0 \pm 0.4$ & $4.2 \pm 0.4$ & Under 4.5 \\
\hline Iodine presence & Not found & Not found & Shall not be permitted \\
\hline $\begin{array}{l}\text { Mass fraction of hot-water insoluble } \\
\text { substances, \% }\end{array}$ & $0.20 \pm 0.02$ & $0.30 \pm 0.03$ & Under 0.40 \\
\hline
\end{tabular}

Table 3. The results of the agar-agar chemical and microbiological safety analysis

\begin{tabular}{|l|c|c|c|}
\hline \multirow{2}{*}{\multicolumn{1}{|c|}{ Indicator }} & \multicolumn{2}{|c|}{ Sample } & \multirow{2}{*}{$\begin{array}{c}\text { GOST } 16280-2002 \\
\text { provisions }\end{array}$} \\
\cline { 2 - 3 } & $\begin{array}{c}\text { The Panreac agar-agar } \\
\text { (Germany) }\end{array}$ & $\begin{array}{c}\text { The Helicon agar-agar } \\
\text { (USA) }\end{array}$ & Under 2.00 \\
\hline Lead, $\mathrm{mg} / \mathrm{kg}$ & $0.15 \pm 0.01$ & $0.08 \pm 0.01$ & Under 0.030 \\
\hline Cadmium, $\mathrm{mg} / \mathrm{kg}$ & Under detection limit & $0.010 \pm 0.005$ & Under 0.500 \\
\hline Arsenic, $\mathrm{mg} / \mathrm{kg}$ & $0.010 \pm 0.005$ & $0.010 \pm 0.005$ & Under 0.02 \\
\hline Mercury, $\mathrm{mg} / \mathrm{kg}$ & Under detection limit & Under detection limit & Under $1.0 \cdot 10^{3}$ \\
\hline QMAFAnM, CFU/g & $0.9 \cdot 10^{2}$ & $3.2 \cdot 10^{2}$ & Shall not be permitted \\
\hline Coliform bacteria, CFU/g & Not found & Not found & Shall not be permitted \\
\hline Proteobacteria & Not found & Not found & Shall not be permitted \\
\hline Pathogenic microorganisms & Not found & Not found & \\
\hline
\end{tabular}


Table 4. The results of analyzing the carrageenans' organoleptic indicators

\begin{tabular}{|l|c|c|c|}
\hline \multirow{2}{*}{ Indicator } & \multicolumn{2}{|c|}{ Sample } & \multirow{2}{*}{$\begin{array}{c}\text { CAS 11114-20-8 } \\
\text { provisions }\end{array}$} \\
\cline { 2 - 4 } & $\begin{array}{c}\text { The Boc Sciences kappa- } \\
\text { carrageenan (USA) }\end{array}$ & $\begin{array}{c}\text { The Newgreen Pharmchem Co. iota- } \\
\text { carrageenan (China) }\end{array}$ & Fine powder \\
\hline $\begin{array}{l}\text { Appearance and } \\
\text { consistency }\end{array}$ & Fine powder & Fine powder & No \\
\hline Odor & No & No & $\begin{array}{c}\text { From yellowish-white to } \\
\text { brown }\end{array}$ \\
\hline Color & Yellowish-white & Yellowish-white & No \\
\hline Taste & No & No & \\
\hline
\end{tabular}

Table 5. Physical-chemical quantities observed when testing carrageenans

\begin{tabular}{|l|c|c|c|}
\hline \multirow{2}{*}{\multicolumn{1}{|c|}{ Indicator }} & \multicolumn{2}{c|}{ Sample } & \multirow{2}{*}{$\begin{array}{c}\text { CAS 11114-20-8 } \\
\text { provisions }\end{array}$} \\
\cline { 2 - 4 } & $\begin{array}{c}\text { The Boc Sciences kappa- } \\
\text { carrageenan (USA) }\end{array}$ & $\begin{array}{c}\text { The Newgreen Pharmchem } \\
\text { Co. Iota-carrageenan (China) }\end{array}$ & Under 12.0 \\
\hline Mass fraction of moisture, $\%$ & $10.5 \pm 1.0$ & $11.0 \pm 1.1$ & $8.0-11.0$ \\
\hline Suspension pH $1: 100$ & $9.5 \pm 1.0$ & $10.0 \pm 1.0$ & Over 5.0 \\
\hline $1.5 \%$ solution viscosity at $75^{\circ} \mathrm{C}, \mathrm{cP}$ & $6.5 \pm 0.3$ & $5.5 \pm 0.3$ & $15.0-40.0$ \\
\hline Mass fraction of sulfates, $\%$ & $25.0 \pm 2.5$ & $18.0 \pm 1.8$ & $15.0-40.0$ \\
\hline Mass fraction of ash, $\%$ & $15.0 \pm 1.5$ & $17.5 \pm 1.8$ & Under 1.00 \\
\hline Mass fraction of ash, acid-insoluble, $\%$ & $0.80 \pm 0.08$ & $0.50 \pm 0.05$ & Under 2.0 \\
\hline $\begin{array}{l}\text { Mass fraction of the substance, acid- } \\
\text { insoluble, } \%\end{array}$ & $1.0 \pm 0.1$ & $1.5 \pm 0.2$ & Under 0.100 \\
\hline $\begin{array}{l}\text { Mass fraction of solvent (ethanol, } \\
\text { isopropanol or methanol), } \%\end{array}$ & Not found & $0.050 \pm 0.005$ & \\
\hline
\end{tabular}

Table 6. The results of carrageenan chemical and microbiological safety analysis

\begin{tabular}{|l|c|c|c|}
\hline \multirow{2}{*}{ Indicator } & \multicolumn{2}{|c|}{ Sample } & \multirow{2}{*}{$\begin{array}{c}\text { CAS 11114-20-8 } \\
\text { provisions }\end{array}$} \\
\cline { 2 - 3 } & $\begin{array}{c}\text { The Boc Sciences kappa- } \\
\text { carrageenan (USA) }\end{array}$ & $\begin{array}{c}\text { The Newgreen Pharmchem } \\
\text { Co. carraggeenan (China) }\end{array}$ & Under 5.0 \\
\hline Lead, $\mathrm{mg} / \mathrm{kg}$ & $0.50 \pm 0.03$ & $1.10 \pm 0.06$ & Under 3.0 \\
\hline Arsenic, $\mathrm{mg} / \mathrm{kg}$ & $0.20 \pm 0.01$ & $0.50 \pm 0.03$ & Under 2.0 \\
\hline Cadmium, $\mathrm{mg} / \mathrm{kg}$ & $0.10 \pm 0.01$ & $0.10 \pm 0.01$ & Under 1.0 \\
\hline Mercury, $\mathrm{mg} / \mathrm{kg}$ & Not found & $1.5 \cdot 10^{1}$ & Under $5.0 \cdot 10^{3}$ \\
\hline QMAFAnM, CFU/g & $1.0 \cdot 10^{2}$ & Not found & Shall not be permitted \\
\hline $\begin{array}{l}\text { Pathogenic microorganisms, } \\
\text { salmonella incl. }\end{array}$ & Not found & Not found & Shall not be permitted \\
\hline Coliform bacteria, CFU/g & Not found & Nound & S \\
\hline
\end{tabular}

Table 7. The results obtained when analyzing the organoleptic indicators of hydroproxypropyl methylcellulose

\begin{tabular}{|l|c|c|c|}
\hline \multirow{2}{*}{ Indicator } & \multicolumn{2}{|c|}{ Sample } & \multirow{2}{*}{$\begin{array}{c}\text { CAS 9004-65-3 } \\
\text { provisions }\end{array}$} \\
\cline { 2 - 3 } & $\begin{array}{c}\text { The Acros HPMC } \\
\text { (Belgium) }\end{array}$ & $\begin{array}{c}\text { The Ashland Aqualon Functional } \\
\text { Ingredients HPMC (USA) }\end{array}$ & $\begin{array}{c}\text { Hygroscopic powder, } \\
\text { granules or fibres }\end{array}$ \\
\hline Appearance and consistency & Hygroscopic powder & Hygroscopic powder & No \\
\hline Odor & No & No & From white to off white \\
\hline Color & White & White & No \\
\hline Taste & No & No & Nonn \\
\hline
\end{tabular}


Hydroproxypropyl methylcellulose organoleptic analysis revealed that the samples investigated are in the form of hygroscopic powder of white color without foreign taste or odor.

The data obtained through testing the physicalchemical indicators of HPMC samples are shown in Table 8.

Experimentally, the physical-chemical indicators of hydroproxypropyl methylcellulose samples in question display acceptable results in regards to mass fraction of moisture, sulfated ash and $\mathrm{pH}$ solution value contents.

Table 9 considers the results of hydroproxypropyl methylcellulose chemical and microbiological safety analysis, as well as heavy metals content and microbiological indicators.

Table 9 proves the conformance of both HPMC samples with the current international food standard CAS 9004-65-3 requirements in terms of chemical and microbiological safety. The HPMC samples under investigation do not contain coliform bacteria and pathogenic microorganisms.

Further, we examined thermodynamic characteristics of the foregoing polysaccharides aqueous solutions.

One of the main methods to do so for biopolymers aqueous solutions and dispersions is high sensitivity differential scanning calorimetry (DSC). The technique is used to measure temperatures and enthalpies of conformational change in biopolymer solutions and dispersions, and to qualitatively describe gel-forming capacity of naturally-occurring polymers.

It is well-known that agar-agar is sparingly soluble in cold water. When swelling, agar-agar forms colloidal solution; the latter produces a strong gel. An initial agar-agar gel-forming concentration of $0.5 \%$ launches intermolecular bonding in the biopolymer solution. Agar-agar creates gel by forming and aggregating double helix, regardless of the proportions of cation and low-molecular weight compounds in the solution.

Fig. 1 shows DSC thermogram for agar-agar aqueous dispersions. Thermodynamic characteristics of the same are displayed in Table 10.

After analyzing the Fig. 1 and Table 10, we were able to see a broad endothermic phase transition from 60 to $95^{\circ} \mathrm{C}$ in agar-agar $0.5 \%$ aqueous solutions, which is inherent to changes from double helix to random coil conformation. An endothermic transition value $\mathrm{Tt}$ of $81.3^{\circ} \mathrm{C}$ was found for the German sample and $84.5^{\circ} \mathrm{C}$ for the American sample.

Therefore, agar-agar-based gels are characterized by high melting temperature (over $80^{\circ} \mathrm{C}$ ) and by ability to withstand the temperature rise. When re-scanned, agar-agar aqueous dispersions proved conformational change to be reversible. Heating transforms agar-agar gels to liquid, and after cooling solidifies them back. The microscopic structure of these gels is not affected (within certain range) by thermal history of the sample. This property is important when creating a stable gel system under the variable environmental conditions.

Table 8. The results of HPMC physical-chemical indicators' analysis

\begin{tabular}{|l|c|c|c|}
\hline \multirow{2}{*}{ Indicator } & \multicolumn{2}{|c|}{ Sample } & \multirow{2}{*}{$\begin{array}{c}\text { CAS 9004-65-3 } \\
\text { provisions }\end{array}$} \\
\cline { 2 - 4 } & $\begin{array}{c}\text { The Acros HPMC } \\
\text { (Belgium) }\end{array}$ & $\begin{array}{c}\text { The Ashland Aqualon Functional } \\
\text { Ingredients HPMC (USA) }\end{array}$ & Under 10.0 \\
\hline Mass fraction of moisture, \% & $8.0 \pm 0.8$ & $8.5 \pm 0.9$ & $5.0-8.0$ \\
\hline Solution pH 1 : 100 & 6.5 & 7.0 & $\begin{array}{c}\text { Under 1.5 for samples with a } \\
\text { viscosity of 50 cP and over. } \\
\text { Under 3.0 for samplea with a } \\
\text { viscosity of 50 cP and under }\end{array}$ \\
\hline
\end{tabular}

Table 9. The results of hydroproxypropyl methylcellulose chemical and microbiological safety indicators' analysis

\begin{tabular}{|l|c|c|c|}
\hline \multirow{2}{*}{\multicolumn{1}{|c|}{ Indicators }} & \multicolumn{2}{|c|}{ Sample } & \multirow{2}{*}{$\begin{array}{c}\text { CAS 9004-65-3 } \\
\text { provisions }\end{array}$} \\
\cline { 2 - 4 } & $\begin{array}{c}\text { The Acros } \\
\text { (Belgium) }\end{array}$ & $\begin{array}{c}\text { The Ashland Aqualon Functional } \\
\text { Ingredients HPMC (USA) }\end{array}$ & Under 2.0 \\
\hline Lead, $\mathrm{mg} / \mathrm{kg}$ & $0.10 \pm 0.01$ & $0.25 \pm 0.01$ & Under 3.0 \\
\hline Arsenic, $\mathrm{mg} / \mathrm{kg}$ & $0.30 \pm 0.01$ & $0.50 \pm 0.03$ & Under 2.0 \\
\hline Cadmium, $\mathrm{mg} / \mathrm{kg}$ & $0.25 \pm 0.01$ & Not found & Under 1.0 \\
\hline Mercury, $\mathrm{mg} / \mathrm{kg}$ & Not found & Not found & Under 1.0 \\
\hline Propylene chlorohydrin, $\mathrm{mg} / \mathrm{kg}$ & Not found & Not found & Under $5.0 \cdot 10^{3}$ \\
\hline QMAFAnM, CFU/g & Not found & Not found & Shall not be permitted \\
\hline $\begin{array}{l}\text { Pathogenic microorganisms, } \\
\text { salmonella incl. }\end{array}$ & Not found & Not found & Shall not be permitted \\
\hline Coliform bacteria, CFU/g & Not found & & \\
\hline
\end{tabular}


Table 10. Thermodynamic characteristics of melting the agar-agars' aqueous dispersions

\begin{tabular}{|l|c|c|}
\hline \multicolumn{1}{|c|}{ Sample } & $\mathrm{T}_{\mathrm{t}},{ }^{\circ} \mathrm{C}$ & $\Delta \mathrm{H}_{\mathrm{t}}, \mathrm{J} / \mathrm{g}$ \\
\hline The Panreac agar-agar & $81.3 \pm 4.1$ & $24.5 \pm 1.2$ \\
\hline The Helicon & $84.5 \pm 4.2$ & $19.6 \pm 1.0$ \\
\hline
\end{tabular}

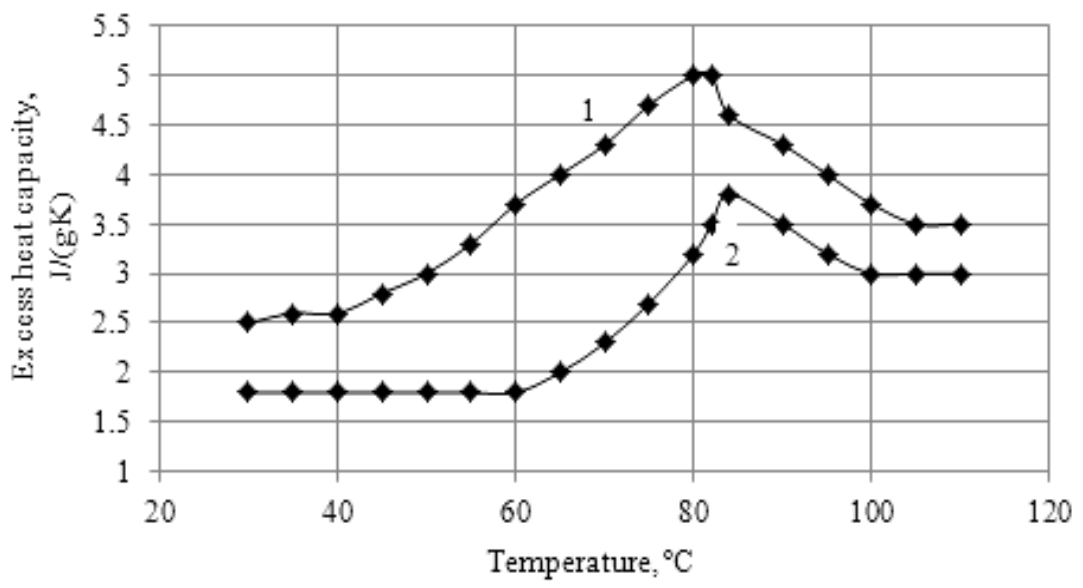

Fig.1. DSC thermogram for agar-agar aqueous solution: 1 - the Panreac agar-agar; 2 - the Helicon agar-agar.

The basic structure of carrageenan is made up of disaccharide units of 3.6-anhydro-D-galactose linked to hemi sulfated D-galactose. The varieties of carrageenan differ in the degree of their disaccharide units' sulphation. The degree of sulphation decreases from iota-carrageenan (two sulphate groups per dissacharide) to kappa-carrageenan (one sulphate group). Higher levels of ester sulfate lower the solubility temperature of the carrageenan producing less strong gels, and thus, contribute to gel inhibition (lambda-carrageenan).

The carrageenans samples concerned varied in the extent of their water-solubility. Kappa-carrageenan dissolved freely in water at $25-30^{\circ} \mathrm{C}$, while iotacarrageenan was only slightly-soluble and formed dispersion.

Fig. 2 shows DSC thermograms for kappa- and iota-carrageenan aqueous solutions. Table 11 demonstrates the thermodynamic characteristics $\left(T_{t}\right.$, $\left.\Delta \mathrm{H}_{\mathrm{t}}\right)$ of the carrageenans under investigation. Kappacarrageenan displays narrow cooperative endothermic transition within a range of $20-50^{\circ} \mathrm{C}$, which agrees with double helix-to-random coil change. Re-scanning of kappa-carrageenan solution (Fig. 1) confirmed the conformational process to be reversible.

For iota-karrageenan we observed a different picture. The first scanning lacked the cooperative calorimetric effect, the polysaccharide being sparingly soluble at room temperature. After heating to $100^{\circ} \mathrm{C}$ we were able to register cooperative endothermic phase transition within $20-40^{\circ} \mathrm{C}$ range. Enthalpy value of iota-carrageenan transition is significantly smaller than the same for kappa-carrageenan (Table 11). This is indicative of a low enthalpy during gel network units' disintegration; in other words, when cooled down the iota-carrageenan solution form a soft, weak gel. The re-scanning (Fig. 2.) shows the reversibility of endothermic phase transition for iotacarrageenan.
Thermodynamic characteristics of carrageenans' aqueous solutions indicate that kappa-carrageenans form more stable gels which have higher melting points. It should be noted that once potassium ion concentration increases in the system, so does temperature of endothermic transition. Thus, the concentration level $\mathrm{KCl}$ in $1 \mathrm{M}$ provides for a transition temperature of $80^{\circ} \mathrm{C}$ and above. This permits the broad-scale adjustment of kappa-carrageenan gel melting points by adding potassium ions into the solution.

That the kappa-carrageenan sample dissolves freely at $25-30^{\circ} \mathrm{C}$ and forms sufficiently strong gel is indicative of the potassium ion impurities presence that are left behind after extracting kappa-carrageenan from algae.

Actually, iota-carrageenans are water-insoluble at room temperature. High density of negatively charged ions (due to presence of two sulfate groups on iotacarrageenan polysaccharide units) does not permit the successful aggregation of polysaccharide chains. To transform iota-carrageenan solution into gel would involve calcium ions. The ions would shield negatively-charged sulphate groups and cross-link biopolymer molecules ensuring the formation of double-helix.

Summing up the thermodynamic data observed, we can conclude that due to its ability to form thermoreversible gel at room temperature, kappa-carrageenan sample is advisable for creating new functional gel systems based on natural polysaccharides. Moreover, kappa-carrageenan gel strength and temperature can be adjusted by changing potassium chloride concentration. This fact has important implications in developing innovative biodegradable polymers.

Chemically, hydroxypropyl methylcellulose (HPMC) samples differ in the degree of their polymer chain branching, carboxyl group methylation, as well as the methylated group distribution along polymer molecule. 
HPMC structural features allow its molecules to retain and combine water, form gels, as well as interact with metal cations and proteins. HPMC is used extensively in food industry due to its gel-forming properties.

The HPMC samples studied are freely watersoluble and form stable viscous solutions.

Fig. 3 shows DSC thermogram for hydroxypropyl methylcellulose aqueous dispersions. Thermodynamic characteristics of these dispersions are illustrated in Table 12.

After analyzing Fig. 3 and Table 12 data, we were able to see narrow cooperative endothermic transition from 42 to $44^{\circ} \mathrm{C}$ in $1.0 \%$ solutions for both HPMC samples, which agrees with double helix - to - random coil type transition. After re-scanning, we noted that conformational change for the HPMC solutions is reversible.

Hence, it is advisable to employ $1.0 \%$ aqueous dispersions of both hydroxypropyl methylcellulose samples in biodegradable polymers production as compound components.

Ultimately, drawing upon the organoleptic, physical, chemical indicators, as well as chemical and microbiological safety indicators of the Pancreac (Germany) and Helicon (USA) agar-agars, the Bos Science (USA) and Newgreen Pharmachem Co.
(China) carrageenans, and the Acros (Belgium) and Ashland Aqualon Functional Ingredients (USA) hydroxypropyl methylcellulose samples, we can conclude the following:

- each of the agar-agar samples conforms with GOST 16280-2002 requirements;

- each of the carrageenan samples conforms with the international food standards CODEX Alimentarius provisions, a CAS 11114-20-8 standard for carrageenans;

- each of the HPMC samples conforms with the international food standard CODEX Alimentarius provisions, a CAS 9004-65-3 standard for hydroxypropyl methylcellulose.

The thermodynamic analysis of natural polysaccharides aqueous solutions revealed that agaragar and hydroxypropyl methylcellulose samples do form stable gel systems and have much to recommend them in biodegradable polymers production. Among carrageenans of interest is kappa-carrageenan that forms a thermally reversible gel at room temperature.

Taking into account all of the above, the agar-agar, hydroxypropyl methylcellulose and kappa-carrageenan tested appear to be a desirable raw material in future development of biodegradable polymers production technologies.

Table 11. Thermodynamic characteristics of melting the carrageenans' aqueous dispersions

\begin{tabular}{|l|c|c|}
\hline \multicolumn{1}{|c|}{ Sample } & $\mathrm{T}_{\mathrm{t}},{ }^{\circ} \mathrm{C}$ & $\Delta \mathrm{H}_{\mathrm{t}}, \mathrm{J} / \mathrm{g}$ \\
\hline The Boc Sciences kappa-carrageenan & $42.0 \pm 2.1$ & $32.2 \pm 1.6$ \\
\hline The Newgreen Pharmchem Co. iota-carrageenan & $31.2 \pm 1.6$ & $5.3 \pm 0.3$ \\
\hline
\end{tabular}

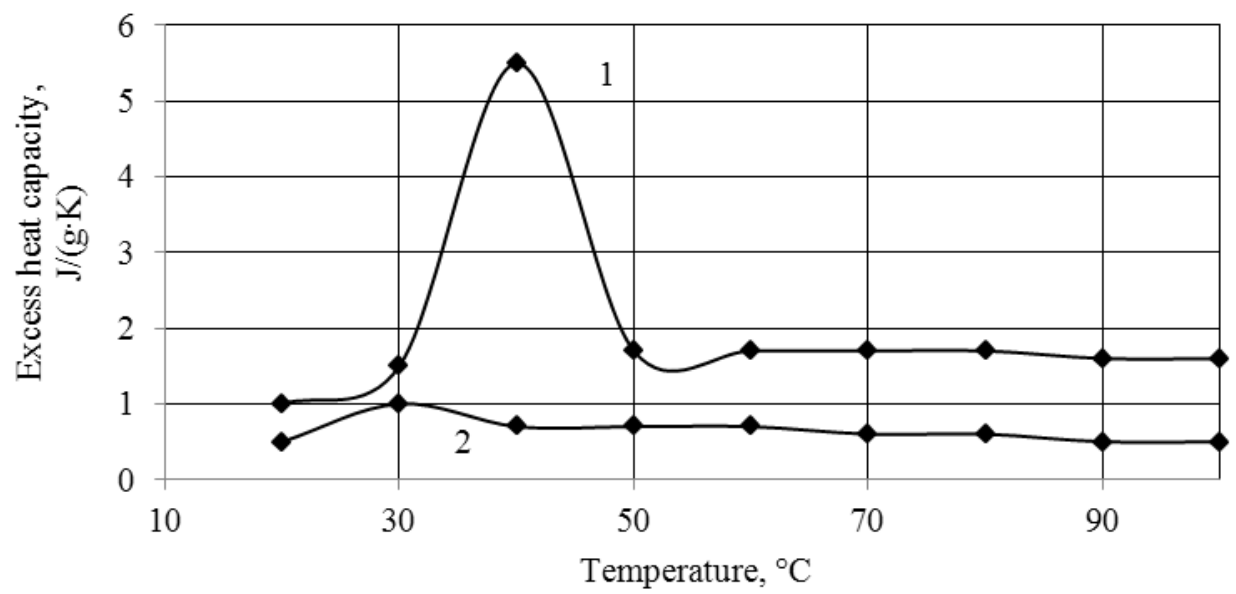

Fig. 2. DSC thermogram for carrageenans aqueous dispersions: 1 - Boc Sciences kappa-carrageenan; 2 - the Newgreen Pharmchem Co. iota-carrageenan.

Table 12. Thermodynamic characteristics of melting the aqueous dispersions of hydroxypropyl methylcellulose

\begin{tabular}{|l|c|c|}
\hline \multicolumn{1}{|c|}{ Sample } & $\mathrm{T}_{\mathrm{t}},{ }^{\circ} \mathrm{C}$ & $\Delta \mathrm{H}_{\mathrm{t}}, \mathrm{J} / \mathrm{kg}$ \\
\hline The Acros hydroxypropyl methylcellulose & $42.5 \pm 2.1$ & $7.7 \pm 0.4$ \\
\hline The Ashland Aqualon Functional Ingredients hydroxypropyl methylcellulose & $43.9 \pm 2.2$ & $8.2 \pm 0.4$ \\
\hline
\end{tabular}




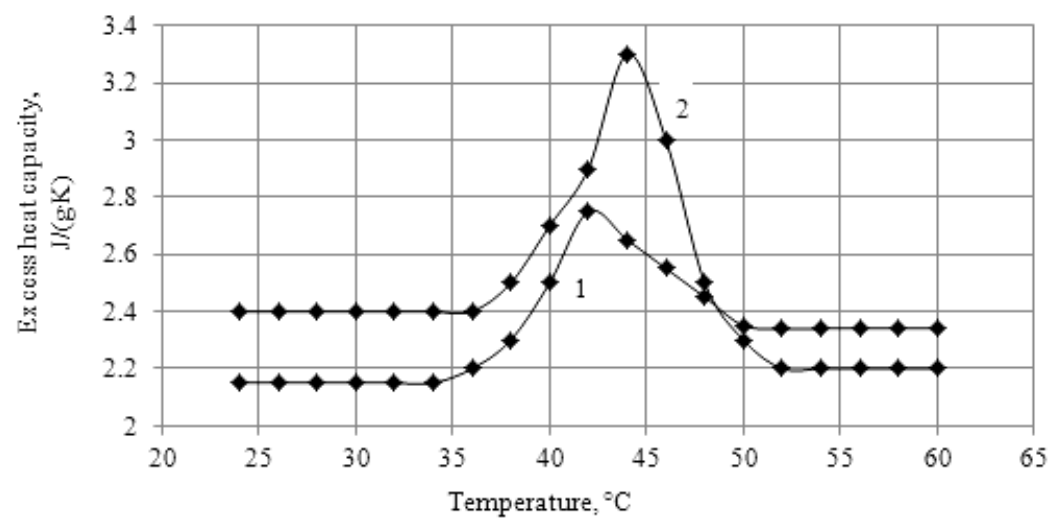

Fig. 3. DSC thermogram of hydroxypropyl methylcellulose aqueous dispersions: 1 - the Acros HPMC; 2 - the Ashland Aqualon Functional Ingredients HPMC.

\section{REFERENCES}

1. Vil'danov F.Sh. Biorazlagaemye polimery - sovremennoe sostoyanie i perspektivy ispol'zovaniya [Biodegradable polymers: the current status and future prospects]. Bashkirskiy khimicheskiy zhurnal [Bashkir Chemical Journal], 2012, vol. 19, no. 1, pp. 135-139.

2. Bakhaeva A.N. Okso-biorazlagaemye polimery kak material dlya sozdaniya sovremennoy upakovki [OXO biodegradable polymer materials for modern packaging]. Molodoy uchenyy [Young Scientist], 2015, vol. 5, no. 85, pp. 122-124.

3. Khasanova G.B. Biorazlagaemye polimery - put' k ustoychivomu razvitiyu prirody i obshchestva [Biodegradable polymers as a direction to ongoing development of society and nature]. Vestnik Kazanskogo tekhnologicheskogo universiteta [Herald of Kazan Technological University], 2014, vol. 17, no. 18, pp. 323-325.

4. Shit S.C. Edible polymers: challenges and opportunities. Journal of Polymers, vol. 2014. 13 p. doi: 10.1155/2014/427259

5. Prajapati V.D. Carrageenan: a natural seaweed polysaccharide and its applications. Carbohydrate Polymers, 2014, vol. 105, pp. 97-112. doi:10.1016/j.carbpol.2014.01.067

6. Vasil'eva, N.G. Biorazlagaemye polimery [Biodegradable polymers]. Vestnik Kazanskogo tekhnologicheskogo universiteta [Herald of Kazan Technological University], 2013, vol. 16, no. 22, pp. 156-157.

7. Tertyshnaya Yu.V. Biorazlagaemye polimery: perspektivy ikh masshtabnogo primeneniya $\mathrm{v}$ promyshlennosti Rossii [Biodegradable polymers: prospects for a broad-scale introduction in Russian industries]. Ekologiya i promyshlennost' Rossii [Ecology and industries in Russia]. 2015, vol. 19, no. 8, pp. 20-25.

8. Belousova, O.S. Izuchenie termodinamicheskikh i reologicheskikh svoystv prirodnykh polimerov, perspektivnykh dlya polucheniya kapsul farmatsevticheskogo naznacheniya [Studying the thermodynamic and rheological properties of naturally occurring polymers for pharmaceutical capsules manufacturing]. Tekhnika i tekhnologiya pishchevykh proizvodstv [Food Processing: Techniques and Technology], 2014, no. 4, pp. 13-19.

9. Dyshlyuk L.S. Kharakteristika organolepticheskikh i fiziko-khimicheskikh svoystv syr'ya dlya polucheniya biorazlagaemykh polimerov [Organoleptic and physical-chemical properties description of raw materials for biodegradable polymers production]. Nauka segodnya: teoriya, metodologiya, praktika, problematika [Science today: theory, methodology, practice, problems]. Warsaw, 2014. pp. 20-24.

10. Ul'rikh E.V. Organolepticheskie, fiziko-khimicheskie i tekhnologicheskie svoystva rastitel'nykh analogov farmatsevticheskogo zhelatina [Organoleptic, physical, chemical and technological properties of vegetarian substitute for pharmaceutical gelatin]. Sovremennye problemy nauki i obrazovaniya [Modern Problems of Science and Education], 2014, no. 5, pp. 161-166.

\section{Dar'ya D. Belova}

Postgraduate Student of the Department of Bionanotechnology, Kemerovo Institute of Food Science and Technology (University), Kemerovo, Russian Federation.

\section{Lyubov S. Dyshlyuk}

Cand.Sci.(Biol.), Senior Lecturer of the Department of Bionanotechnology, Kemerovo Institute of Food Science and Technology (University), Kemerovo, Russian Federation. 